\title{
FRAKSI SERAT KULIT UBI KAYU (Manihot utilissima) YANG DIFERMENTASI DENGAN RAGI TAPE (Saccharomyces cerevisae)
}

\author{
E. IRAWATI, LIL FITRI, T. ADELINA DAN ELVIRIADI \\ Fakultas Pertanian dan Peternakan Universitas Islam Negeri Sultan Syarif Kasim Riau \\ Kampus II Raja Ali Haji Jln. Soebrantas KM 16 Panam-Pekanbaru \\ Email : eviirawati2013@gmail.com
}

\begin{abstract}
Feed is one of the important factors in the livestock business. Cassava skin can be made into one alternative feed by fermentation. This study purposed to know the content of the fiber fraction such as neutral detergent fiber (NDF), acid detergent fiber (ADF), acid detergent lignin (ADL), hemicellulose and sellulose cassava skin with tape yeast on different fermentation time. This research was conducted from September to October 2016 at Laboratory of Nutrition and Chemistry, Faculty of Agriculture and Animal Husbandry of State Islamic University Sultan Syarif Kasim of Riau. This Research was conducted by experiment. The study design used was completely randomized design (CRD) consisting of 4 treatments and 5 replications. The treatment in this study was fermentation time $A=0$ days, $B=3$ days, $C=6$ days and $D=9$ days. The results showed that the different fermentation time (9 days) hight significantly $(P<0.01)$ the content of $A D F$ and no significant $(P>0.05)$ in NDF, ADL, hemicellulose and sellulose. As conclusion that the different fermentation time was gived effect the content of ADF but no significantly $(P>0.05)$ to content NDF,ADL, hemicellulose and sellulose KUKF.
\end{abstract}

Keywords : cassava skin, NDF, ADF, ADL, hemiselulosa, selulosa, fermentation

\section{PENDAHULUAN}

Kulit ubi kayu merupakan limbah agroindustri yang berpotensi dijadikan sebagai salah satu pakan alternatif untuk ternak. Meningkatnya produk ubi kayu di Riau menyebabkan ketersediaan limbah ini ada setiap tahun. Menurut data Badan Pusat Statistik Riau (2013) luas areal perkebunan ubi kayu di Riau pada tahun 2013 adalah 3863 Ha dengan produksi 103.070 ton/tahun. Setiap kilogram ubi kayu dapat menghasilkan 15-20\% kulit ubi kayu (Nurhayani et al., 2000) dan berpotensi mencemari lingkungan. Limbah ini apabila diolah dengan baik menggunakan teknologi pengolahan pakan yang tepat akan menghasilkan bahan baku pakan (utama atau suplemen) yang berkualitas juga sebagai sumber karbohidrat dan energi penting dalam pakan (Aro 2008; Anaeto et al., 2013).

Kulit ubi kayu mempunyai keterbatasan dalam pemanfaatan sebagai bahan baku pakan yaitu tingginya kandungan serat kasar (Busairi dan
Hersoelistyorini, 2009). Kandungan Serat Kasar (SK) dalam kulit ubi kayu sebesar 28-31\%. Serat kasar termasuk didalamnya lignin, selulosa dan hemiselulosa merupakan faktor utama penyebab rendahnya kecernaan pakan, efisiensi pakan dan penurunan performa (Murni et al., 2008). Kandungan nutrisi lainnya seperti Lemak Kasar (LK) 4,02\%; BETN 56,06\%; abu 2,32\% (Nuraini dkk., 2007), di samping itu, juga terdapat HCN sebanyak $225 \mathrm{ppm}$, lignin 12,56\% dan selulosa 14,00\% (Lira, 2012).

Untuk meningkatkan kualitas dan menurunkan faktor pembatas dari kulit ubi kayu serta pemanfaatan dalam ransum ternak dapat maksimal, maka diperlukan teknologi pengolahan pakan yang sesuai untuk meningkatkan kualitas nutrisi dan menurunkan kandungan serat kasar terutama lignin dan selulosa. Salah satu upaya yang dapat dilakukan yaitu dengan melakukan teknologi fermentasi dengan bantuan ragi tape (Saccharomyces cereviseae). 
Fermentasi pada dasarnya adalah memperbanyak mikroorganisme dan meningkatkan kualitas nutrien substrat dan menambah aroma menjadi lebih disukai (Winarno dkk., 1980). Ragi tape bersifat katabolik atau memecah komponen kompleks menjadi zat yang lebih sederhana sehingga lebih mudah dicerna oleh ternak. Spesies Aspergillus flavus relatif tidak aktif dibandingkan jamur selulolitik lain, tapi enzim yang dihasilkan oleh Aspergillus orizae dan Aspergillus flavus mampu mendegradasi sellulosa dan juga menghidrolisis xylon (Susanto dan Saneto, 1994).

Nuraini dkk. (2007) menyatakan fermentasi kulit ubi kayu dengan kapang Neurospora crasa hanya dapat menurunkan serat kasar sekitar 50 persen dari serat kasar kulit ubi kayu, karena kapang Neurospora crasa tersebut sedikit menghasilkan enzim selulase. Ditambahkan bahwa keberhasilan fermentasi media padat sangat tergantung pada kondisi optimum yang diberikan. Faktor-faktor yang mempengaruhinya adalah komposisi dan ketebalan subtrat, dosis inokulum, lama fermentasi serta suhu dan $\mathrm{pH}$. Semakin tinggi dosis maka semakin cepat pertumbuhan mikroba dan semakin lama fermentasi dilakukan maka semakin banyak pula zat makanan dirombak (Winarno, 1980).

Berdasarkan latar belakang di atas dan belum diketahuinya pengaruh lama fermentasi kulit ubi kayu dengan ragi tape (Saccharomyces cereviseae) terhadap fraksi serat kulit ubi kayu, perlu dilakukan penelitian yang bertujuan untuk mengetahui kandungan fraksi serat yaitu NDF, ADF, ADL, hemiselulosa dan selulosa kulit ubi kayu dengan inokulan ragi tape (Saccharomyces cereviseae) pada lama fermentasi yang berbeda, sehingga bisa dimanfaatkan sebagai bahan baku pakan yang berkualiatas dan tersedia sepanjang tahun.

\section{METODE PENELITIAN}

\section{Waktu dan Tempat}

Penelitian ini dilaksanakan bulan September sampai Oktober 2016 di Laboratorium Ilmu Nutrisi dan Kimia Fakultas Pertanian dan Peternakan Universitas Islam Negeri Sultan Syarif Kasim Riau Pekanbaru.

\section{Bahan dan Alat}

Bahan yang digunakan untuk fermentasi adalah kulit ubi kayu, dedak padi, ragi tape (Saccharomyces cereviseae). Bahan untuk analisis fraksi serat yaitu aquades 1 liter, Natrium-Lauryl Sulfat, Tritiplek III, Natrium borat, Disodium Hydrogen Phosphate, $\mathrm{H}_{2} \mathrm{SO}_{4}$, CTAB (Cetyl Trymethyl Amonium Bromide) oktanol dan alkohol.

Alat yang digunakan adalah kantong plastik, timbangan, pisau, baskom, talenan, kukusan dan sendok pengaduk (fermentasi), cawan, crusibel, gelas piala $1.000 \mathrm{~mL}$, spatula, pipet tetes, timbangan analitik, fibertex yang dilengkapi dengan hot extraction dan cold extraction, pemanas, listrik, oven, tanur, desikator dan gelas ukur (analisis fraksi serat).

\section{Metode Penelitian}

Metode yang digunakan dalam penelitian ini adalah metode eksperimen menggunakan Rancangan Acak Lengkap (RAL) menurut Steel dan Torrie (1995) dengan 4 perlakuan dan 5 ulangan.

$$
Y i j=\mu+a i+\varepsilon i j
$$

Keterangan:

Yij : Pengamatan perlakuan ke-i dan ulangan ke-j

$\mu \quad$ : Rataan umum

ai : Pengaruh perlakuan ke-i

cij : Pengaruh galat pada perlakuan kei dan ulangan ke-j

i : 1, 2, 3 dan 4 (perlakuan)

j $: 1,2,3,4$ dan 5 (ulangan) 
Perlakuan adalah :

A1= Lama fermentasi 0 hari

A2= Lama fermentasi 3 hari

A3 = Lama fermentasi 6 hari

A4= Lama fermentasi 9 hari

Dosis ragi yang dipakai adalah $3 \mathrm{~g} / \mathrm{kg}$ substrat. Substrat yang digunakan terdiri dari $80 \%$ kulit ubi kayu dan 20\% dedak. Lama fermentasi yang digunakan adalah 0, 3, 6 dan 9 hari (Nurhayani et al. 2000) dan komposisi substrat berdasarkan Adelina (2005).

\section{Peubah yang diukur}

Peubah yang diukur adalah komposisi fraksi serat yaitu : Neutral detergent fibre, Acid detergent fibre, Acid detergent lignin, hemiselulosa dan selulosa.

\section{Prosedur Penelitian}

Pembuatan kulit ubi kayu fermentasi diawali dengan pencacahan kulit ubi kayu (2-3 cm), dicuci, ditiriskan sampai kering (KA 80\%), kemudian kulit ubi kayu (800 g) dan dedak (200 g) dikukus (15 menit), diangkat, didinginkan (hangat kuku), dilakukan pencampuran substrat dengan ragi tape $(3 \mathrm{~g})$, diaduk sampai homogen, dimasukkan ke dalam kantong plastik (1 kg), dihekter, dilobangi dengan jarum (aerob), diberi label dan disimpan dalam inkubator sesuai masing masing perlakuan. Setelah waktu fermentasi berakhir dilakukan pemanenan dan analisis fraksi serat (NDF, ADF, ADL, selulosa dan hemiselulosa).

HASIL DAN PEMBAHASAN

\section{Fraksi Serat KUKF.}

Rataan fraksi serat Kulit Ubi Kayu Fermentasi (KUKF) dilihat pada Tabel 1

Tabel 1. Rataan Fraksi Serat KUKF (\%)

\begin{tabular}{|c|c|c|c|c|}
\hline \multirow{2}{*}{ Parameter } & \multicolumn{4}{|c|}{ Perlakuan } \\
\hline & $\mathrm{A}$ & $\mathrm{B}$ & $\mathrm{C}$ & $\mathrm{D}$ \\
\hline NDF & $59,25 \pm 4,40$ & $57,61 \pm 4,06$ & $57,16 \pm 4,70$ & $63,26 \pm 3,25$ \\
\hline $\mathrm{ADF}$ & $35,48^{a} \pm 1,90$ & $39,98^{a} \pm 3,18$ & $38,11^{\mathrm{a}} \pm 4,67$ & $45,53 a \pm 2,11$ \\
\hline ADL & $16,02 \pm 4,20$ & $16,85 \pm 7,51$ & $14,75 \pm 5,30$ & $15,20 \pm 5,62$ \\
\hline Hemiselulosa & $23,77 \pm 4,56$ & $17,63 \pm 2,30$ & $19,05 \pm 1,46$ & $17,73 \pm 7,06$ \\
\hline Selulosa & $16,25 \pm 3,98$ & $18,66 \pm 10,09$ & $23,00 \pm 5,04$ & $27,07 \pm 0,30$ \\
\hline
\end{tabular}

Ket : Superskrip yang berbeda pada baris yang sama memperlihatkan perbedaan sangat sangat nyata $(\mathrm{P}<0,01)$ Data adalah rataan \pm standar deviasi

\section{Kadar NDF}

Data pada Tabel 1. menunjukkan lama fermentasi 0-9 hari tidak berpengaruh nyata $(\mathrm{P}>0,05)$ terhadap kadar NDF KUKF. Tidak berbeda nyata $(\mathrm{P}>0,05)$ kadar NDF KUKF diduga karena Bakteri Asam Laktat (BAL) masih berada di fase pertumbuhan lambat dan perlu penyesuaian dengan lingkungan baru, hal ini menyebabkan Bakteri Asam Laktat belum mampu merombak ikatan lignoselulosa dan lignohemiselulosa secara optimal sehingga kadar NDF KUKF tidak berbeda. Allaily et al. (2011) menyatakan Bakteri Asam Laktat akan mengalami perkembangan secara logaritmik pada umur 21 hari, sementara lama fermentasi hanya sampai 9 hari.

Kadar NDF yang didapat pada penelitian ini berkisar 57,16\%-63,26\%. Nilai yang didapat pada penelitian ini lebih tinggi dibanding yang dilaporkan Melati dan Sunarno (2016) menggunakan kulit ubi kayu segar yang ditambahkan enzim selulase Bacillus subtilis (25\%) 
didapat perubahan kadar NDF dari $39,75 \%$ menjadi $33,28 \%$.

\section{Kadar ADF}

Data pada Tabel 1. menunjukkan lama fermentasi 0-9 hari berpengaruh sangat nyata $(\mathrm{P}<0,01)$ terhadap kadar ADF KUKF. Rendahnya kadar ADF KUKF pada lama fermentasi 9 hari dibandingkan 0, 3 dan 6 hari hal ini disebabkan oleh $\mathrm{pH}$, dimana $\mathrm{pH}$ pada lama fermentasi 9 hari $(5,16)$ lebih tinggi dibanding 0 hari $(4,50)$, 3 hari $(4,52)$ dan 6 hari $(4,51)$, sehingga asam laktat yang diproduksi juga lebih banyak akibatnya kemampuan untuk meningkatkan ADF lebih maksimal. Selain itu juga disebabkan tidak terjadi pemecahan ikatan lignoselulosa yang menyebabkan selulosa dan hemiselulosa yang merupakan bagian dari ADF tidak terlepas dan lignin tidak dikonversi menjadi gula sederhana, hal ini menyebabakan kandungan ADF meningkat. Lynch (1987) menyatakan perombakan dinding sel dan isi sel yang berupa selulosa dan hemiselulosa dari ikatan lignoselulosa menyebabkan penurunan kandungan ADF untuk selanjutnya selulosa dan hemiselulosa dikonversi menjadi gula sederhana untuk dan digunakan sebagai sumber energi bagi mikroba.

Kadar ADF yang didapat pada penelitian ini berkisar 35,48\%-45,53\%. Nilai yang didapat pada penelitian ini lebih rendah dibandingkan Badarina (2013) menggunakan substrat kulit kopi yang difermentasi dengan Pleurotus ostreatus didapat perubahan kadar ADF dari sebelum fermentasi $87,18 \%$ menjadi $74,08 \%$ setelah fermentasi.

\section{Kadar ADL}

Data pada Tabel 1. menunjukkan lama fermentasi 0-9 hari tidak berpengaruh nyata $(\mathrm{P}>0,05)$ terhadap kadar $\mathrm{ADF}$ KUKF. Kadar ADL yang didapat pada penelitian ini berkisar 14,75\%-16,85\%.
Tidak berbeda nyata $(\mathrm{P}>0,05)$ kadar ADL KUKF pada lama fermentasi 0-9 hari diduga karena pemanfaatan substrat yang belum optimal oleh mikroba dimana lignoselulosa yang dihasilkan mikroba selama proses fermentasi belum mampu merombak kandungan lignin, karena lama fermentasi yang masih kurang untuk mikroba mendegradasi lignoselulosa pada substrat. Miswandi (2009) menyatakan kecernaan terhadap bahan pakan juga dipengaruhi oleh kadar lignin yang terkandung dalam bahan pakan. Surono et al. (2012) menambahkan lama pemeraman 4 minggu dapat memberikan waktu yang cukup bagi mikroba untuk mendegradasi substrat.

Penyebab lain tidak berbeda nyata $(\mathrm{P}>0,05)$ kadar ADL KUKF pada penelitian ini berhubungan dengan kadar NDF yang didapat pada penelitian ini juga tidak berbeda pada setiap perlakuan. Menurut Van Soest (1982) dalam bahan makanan terdapat fraksi serat yang sukar dicerna yaitu Neutral Detergent Fiber (NDF). NDF adalah zat yang tidak larut dalam detergent netral dan merupakan bagian terbesar dari dinding sel tanaman. NDF terdiri dari selulosa, hemiselulosa, lignin, silika dan protein fibrosa.

\section{Kadar Hemiselulosa}

Data pada Tabel 1. menunjukkan lama fermentasi 0-9 hari tidak berpengaruh nyata $(\mathrm{P}>0,05) \quad$ terhadap kadar hemiselulosa KUKF. Tidak berbeda nyata $(\mathrm{P}>0,05)$ kadar hemiselulosa KUKF pada penelitian ini disebabkan oleh komposisi substrat tidak memberikan pengaruh terhadap kadar NDF KUKF. Selain itu kerja mikroba belum optimal merombak ikatan ligno hemiselulosa dimana hemiselulosa masih berikatan dengan lignin. Senjaya dkk. (2010) menyatakan ikatan hemiselulosa akan terdegradasi dan larut dalam deterjen netral setelah derajat keasaman mencapai kondisi yang optimal untuk melonggarkan fraksi serat. 
Kadar hemiselulosa KUKF yang didapat pada penelitian ini berkisar $17,63 \%-23,77 \%$. Kadar hemiselulosa yang didapat pada penelitian ini lebih rendah dibandingkan Mokoginta (2014) yang menggunakan kulit nanas yang difermentasi dengan penambahan molases (20\%) didapat perubahan kadar hemi selulosa dari $24,31 \%$ menjadi $28,69 \%$.

\section{Kadar Selulosa}

Data pada Tabel 1. menunjukkan lama fermentasi 0-9 hari tidak berpengaruh nyata $(\mathrm{P}>0,05)$ terhadap kadar selulosa KUKF. Tidak berbeda nyata $(\mathrm{P}>0,05)$ kadar selulosa KUKF pada penelitian ini disebabkan oleh Bakteri Asam Laktat masih berada dalam fase adatasi sehingga belum mampu meningkatkan kadar selulosa KUKF berarti pemanfaatan substrat belum optimal sehingga kandungan selulosa tidak terjadi peningkatan. Menurut Amnur (2015) enzim selulase merupakan salah satu enzim yang dihasilkan oleh mikroorganisme yang berfungsi untuk mendegradasi selulosa menjadi glukosa. Fogarty (1983) menyatakan selulosa merupakan komponen utama penyusun dinding sel tumbuhan, selain hemiselulosa dan lignin. Kebanyakan selulosa berasosiasi dengan lignin, oleh karena itu sering disebut juga lignoselulosa. Selulosa, hemiselulosa dan lignin dihasilkan dari proses fotosintesis.

Kadar selulosa yang didapat pada penelitian ini berkisar 16,25\%-27,07\%. Kadar selulosa yang didapat pada penelitian ini berbeda dibandingkan Maneerat et al. (2013) menggunakan silase kulit nanas didapatkan kandungan selulosa $32,57 \%$.

\section{KESIMPULAN DAN SARAN}

\section{Kesimpulan}

Lama fermentasi yang berbeda memberikan pengaruh terhadap kandungan ADF KUKF, namun belum berpengaruh terhadap kandungan NDF, ADL, hemiselulosa dan selulosa KUKF.

\section{Saran}

Disarankan untuk melakukan penelitian lanjutan menggunakan inokulum lainnya.

\section{DAFTAR PUSTAKA}

Adelina, T. 2005. Pengaruh komposisi substrat dan dosis inokulum laru terhadap nilai gizi ampas sagu (Metroxylon sp) fermentasi. Laporan Penelitian UIN Suska Riau. Pekanbaru.

Allaily., Ramli, N., dan Ridwan, R. 2011 Kualitas silase ransum komplit berbahan baku pakan lokal.Jurnal Agripet.11(2):35-40

Amnur, F. Y. 2015. Fraksi Serat Silase Daun Sagu Menggunakan Komposisi Substrat dan Lama Fermentasi Berbeda. Skripsi. Fakultas Pertanian dan Peternakan. Universitas Islam Sultan Syarif Kasim Riau. Pekanbaru.

Anaeto, M., A. F. Sawyerr, T. R. Alli, G.O. Tayo, J. A. Adeyeye, and A. O. Olarinmoye. 2013. Cassava Leaf Silage and Cassava Peel as Dry Season Feed for West African Dwarf Sheep. Global Journal of Science Frontier Research 13(2): 5 p.

Aro, S. O. 2008. "Improvement in The Nutritive Quality of Cassava and Its by Products through Microbial Fermentation." African Journal of Biotechnology 7 (25): 4789-97

Badan Pusat Statistika Riau. 2013.http://riau.bps.go.id/publikasionline/riau-dalam angka 2010 / perkebunan. html. Diakses 2 Maret 2014.

Badarina, I. 2013. Pemanfaatan kulit buah kopi produk biokonversi Peurotus ostreatus untuk meningkatkan kesehatan dan performa kambing laktasi. Disertasi IPB. Bogor.

Busairi, A. M., and W. Hersoelistyorini. 2009. Pengkayaan Protein Kulit Ubi Kayu 
Melalui Proses Fermentasi: Optimasi Nutrien Subtrat Menggunakan Respon Surface Methodology. dalam Seminar Nasional Teknik Kimia Indonesia, 6 hal.

Fogarty, W. M. 1983. Microbial Enzimes and Biotechnology. Applied Sciences Publ., London.

Lira. Y. M, 2012. Pengaruh komposisi susbtrat kulit umbi ubi kayu dan ampas tahu fermentasi dengan Phanerochaete chrysosporium terhadap perubahan nutrisi. Skripsi. Fakultas Peternakan. Universitas Andalas. Padang.

Lync, J. M. 1982. Utilization of lignocelulosic wastes. The Soc. For Applied Bacteriology SymP. Series No.16.

Maneerat, W., Prasanpanich, S., Kongmum, P., Sinsmut, W and Tumwasorn, S. 2013. Feeding total mixed fiber on feed intake and milk production in mid-lactating dairy cows. Kasetsar J. (Nat.Sci.) 47: 571-580.

Melati, I.,M. T. D. Sunarno, 2016. Pengaruh Enzim Selulase Bacillus subtilis terhadap Penurunan Serat Kasar Kulit Ubi Kayu untuk Bahan Baku Pakan Ikan. Widyariset.1(2):57-56.

Miswandi. 2009. Analisis Komponen Daun Kelapa Sawit yang Difermentasi dengan Feses Ayam. Skripsi. Fakultas Pertanian dan Peternakan. Universitas Islam Sultan Syarif Kasim Riau. Pekanbaru.

Mokoginta, I. 2014. Fraksi Serat Silase Kulit Nanas yang Difermentasi dengan Penambahan Molases pada Level yang Berbeda. Skripsi. Fakultas Pertanian dan Peternakan. Universitas Islam Negeri Sultan Syarif Kasim Riau. Pekanbaru.

Murni, R., Suparjo, Akmal, and B. L. Ginting. 2008. Teknologi Pemanfaatan Limbah Untuk Pakan. Labotarorium Makanan Ternak. Fakultas Peternakan. Universitas Jambi. Jambi.
Nuraini, S. A. Latif dan Sabrina. 2007. Peningkatan kualitas limbah aroindustri dengan kapang Neurospora crasa sebagai pakan ternak unggas. Laporan penelitian hibah bersaing, DIKTI. Lembaga Penelitian Universitas Andalas, Padang.

Nurhayani. H. M., J. Nuryati, dan I.P.A. Nyoman. 2000. Peningkatan kandungan protein kulit umbi ubi kayu melalui proses fermentasi. Departemen Biologi. Fakultas MIPA. Institut Teknologi Bandung. Bandung.

Senjaya, T. Oka. T. Dhalika. A. Budiman. I. Hernamawan dan Mansyur. 2010. Pengaruh Lama Penyimpanan dan Aditif dalam Pembuatan Silase terhadap Kandungan NDF dan ADF Silase Rumput Gajah. Jurnal Ilmu Ternak. 10(2) : 85-89.

Steel, R.G. and J.H. Torrie. 1995. Prinsip dan Prosedur Statistika Suatu Pendekatan Biometrik. PT. Gramedia Pustaka Utama. Jakarta.

Surono., Prastyawan, R., dan Tampoebolon, B. 2012. Peningkatan kualitas tongkol jagung melalui teknologi amoniasi fermentasi (amofer) terhadap kecernaan bahan kering dan bahan organik serta protein total secara in vitro. Animal Agriculture Journal. 1(1):612621.

Susanto, T. dan B. Saneto. 1994. Teknologi Pengolahan Hasil Pertanian. Bina Ilmu. Surabaya.

Van Soest, P. J.1982. Nutritional Ecology of The Ruminan. O dan B Book, Corvalilis, Oregon. http://books.google.co.id. Diakses 20 Mei 2014.

Winarno, F. G., S. Fardiaz dan D. Fardiaz, 1980. Pengantar Teknologi Pangan. Gramedia Pustaka Utama, Jakarta. 